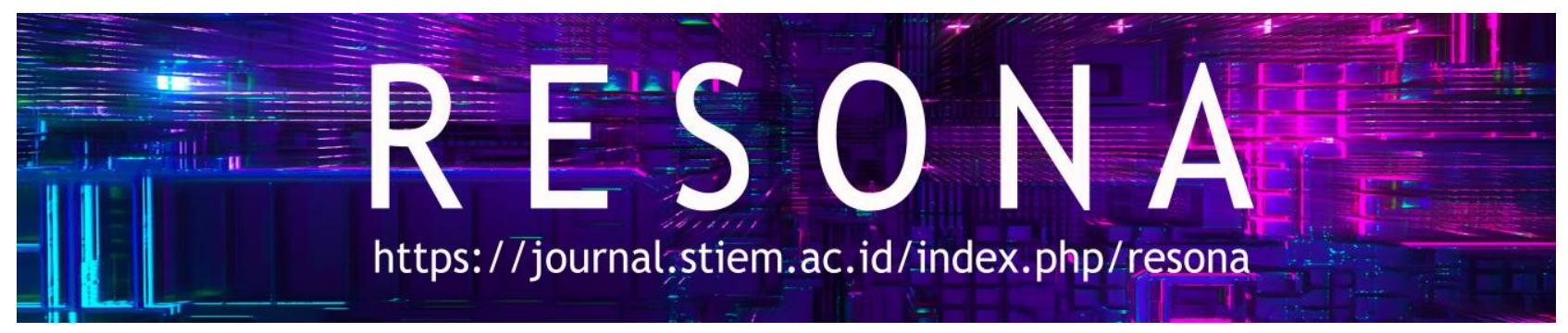

\title{
Pendampingan Pengelolaan Dan Penyusunan Laporan Keuangan Pada Badan Usaha Milik Desa (Bumdes) Ladongi, Kecamatan Malangke, Kabupaten Luwu Utara
}

Junaidi $^{l}$

${ }^{1}$ Universitas Muhammadiyah Palopo

INFO NASKAH

Diserahkan

24 Maret 2020

Diterima

24 Maret 2020

Diterima dan Disetujui 10

Juni 2020

Kata Kunci:

BUMDes,

Pengelolaan Laporan

Keuangan

Keywords:

BUMDes, Management

of Financial Statements

\section{ABSTRAK}

Tujuan dari pengabdian masyarakat ini adalah untuk mendampingi pengelola Badan Usaha Milik Desa (BUMDes) di desa Ladongi, Kecamatan Malangke, Kabupaten Luwu Utara untuk meningkatkan kualitas pengelolaan dan penyusunan laporan keuangan sebagai mitra dalam kegiatan kuliah kerja nyata pengabdian masyarakat (KKN-PM) yang bergerak di bidang usaha perdagangan berupa penjual sarana perkebunan seperti pupuk, pestisida, dan lain-lain. Kesulitan yang dialami mitra adalah pengelolaan dan penyusunan laporan keuangan serta pencatatan transaksinya belum rapi. Melalui serangkaian kegiatan pendampingan yang dilakukan bersama mitra, diperoleh kemajuan sehingga mitra binaan bisa melakukan pencatatan transaksi secara rapi dan penyusunan laporan keuangan sesuai standar akuntansi.

Abstract. This community service aims to assist the management of VillageOwned Enterprises (BUMDes) in the village of Ladongi, Malangke District, North Luwu Regency. This program designed to improve the quality of management and preparation of financial statements as partners in real community service work activities (KKN-PM) that move in the business sector of trading in the form of sellers of plantation facilities such as fertilizers, pesticides, and others. Difficulties experienced by partners are the management and preparation of financial statements, and the recording of transactions is not neat. Through a series of mentoring activities carried out with partners, progress has been made so that the fostered partners can keep records of transactions neatly and prepare financial reports under accounting standards. 


\section{Pendahuluan}

Kabupaten Luwu Utara merupakan kabupaten yang terletak di bagian paling utara dari Provinsi Sulawesi Selatan. Salah satu kecamatan di Kabupaten Luwu Utara yaitu Kecamatan Malangke. Adapun secara geografis Kecamatan Malangke terletak pada 20 41' 8', 20 55' 36" lintang Selatan dan 120 0 14 ' 50" -120 0 24 ' 6" Bujur Timur dengan batasnya sebelah selatan yakni kecamatan Baebunta, sebelah Timur berbatasan dengan Kecamatan Malangke, sebelah Barat berbatasan dengan Kabupaten Luwu, sedangkan sebelah utara berbatasan dengan Teluk Bone dengan luas wilayah sekitar 214,05 Km², pemerintah Kecamatan Malangke membawahi 13 desa (Sari, 2019).

Desa sebagai pemerintah yang secara langsung dan riil menyentuh kebutuhan masyarakat untuk disejahterakan. Jika desa mampu secara mandiri menyediakan kebutuhan warganya, maka desa telah mampu mensejahterakan warga sekaligus mengadakan pendapatan bagi dirinya. Desa merupakan basis sistem kemasyarakatan bangsa yang kokoh untuk mengembangkan sistem politik, sosial, budaya, ekonomi, dan hankam. Dalam rangka mengakomodasi potensi desa dan pemenuhan kebutuhan warga desa, melalui UU No. 32 tahun 2004 tentang Pemerintah Daerah pemerintah memberikan dukungan besar agar desa memiliki badan usaha yang mampu mengembangkan dan menggerakkan perekonomian lokal.

Upaya pemerintah dalam pengembangan basis ekonomi di pedesaan sudah semenjak lama dijalankan. Salah satu program yang diadakan oleh pemerintah adalah pendirian Badan Usaha Milik Desa (BUMDes). Badan usaha ini sesungguhnya telah diamanatkan di dalam UU No. 32 Tahun 2004 tentang Pemerintahan Daerah (bahkan oleh Undang-Undang sebelumnya, UU 22/1999) dan Peraturan Pemerintah (PP) No. 71 Tahun 2005 Tentang Desa. Pendirian badan usaha tersebut harus disertai dengan upaya penguatan kapasitas dan didukung oleh kebijakan daerah (Kabupaten/Kota) yang memfasilitasi dan melindungi usaha ini dari ancaman persaingan para pemodal besar. BUMDes sebagai suatu lembaga ekonomi modal usahanya dibangun atas inisiatif masyarakat dan menganut asas mandiri.

Pendirian BUMDes didasarkan pada kebutuhan dan potensi desa, sebagai upaya peningkatan kesejahteraan masyarakat. Berkenaan dengan perencanaan dan pendiriannya, BUMDes dibangun atas prakarsa (inisiasi) masyarakat dan tentunya dukungan dari pemerintah desa mengingat BUMDes ini dimiliki oleh desa dan dikelola secara bersama dan sumber modal usaha bersumber dari desa (51\%) dan dari masyarakat (49\%) melalui penyertaan modal (saham atau andil), operasionalisasinya menggunakan falsafah bisnis yang berakar dari budaya lokal serta bidang usaha yang dijalankan didasarkan pada potensi dan hasil informasi pasar. 
Ini berarti pemenuhan modal usaha BUMDes harus bersumber dari masyarakat. Meskipun demikian, tidak menutup kemungkinan BUMDes dapat mengajukan pinjaman modal kepada pihak uar, seperti dari Pemerintah Desa atau pihak lain, bahkan melalui pihak ketiga. Ini sesuai dengan peraturan perundang-undangan (UU 32 tahun 2004 tentang Pemerintahan Daerah Pasal 213 ayat 3.

\section{Masalah}

Keberadaan BUMDes menjadi salah satu pertimbangan untuk menyalurkan inisiatif masyarakat desa, mengembangkan potensi desa, mengelola dan memanfaatkan potensi sumber daya alam desa, mengoptimalkan sumber daya manusia (warga desa) dalam pengelolaannya, dan adanya penyertaan modal dari pemerintah desa dalam bentuk pembiayaan dan kekayaan desa yang diserahkan untuk dikelola sebagai bagian dari BUMDes. Namun dalam pelaksanaannya salah satu masalah yang dihadapi pengelola BUMDes adalah kurangnya tenaga sumber daya manusia dalam pengelolaan laporan keuangan.

Untuk menjawab permasalahan di atas, maka solusi yg ditawarkan adalah sebagai berikut:

1. Perlu dilakukan pemberdayaan masyarakat melalui peningkatan pengelolaan Badan Usaha Milik Desa (BUMDes) dengan melakukan pelatihan dan pendampingan.

2. Perlu dilakukan peningkatan kapasitas pengelola BUMDes Desa Ladongi dalam pengelolaan usaha melalui bimbingan teknis.

\section{Target Dan Luaran}

Tim program KKN-PPM kelompok aparat desa di Desa Ladongi, Kecamatan Malangke, Kabupaten Luwu Utara menargetkan khusus kepada pengelola BUMDes untuk menjadi sasaran program dengan pengetahuan sistem pengelolaan dan penyusunan laporan keuangannya, khususnya dalam perencanaan dan pengelolaan keuangan sampai pada proses pelaporan dan mengisi data oleh pengelola sehingga memperoleh luaran dalam pengisian data administrasi BUMDes terutama dalam pembuatan laporan tertulis pertanggungjawaban keuangan sebagai berikut buku kas umum, buku kas pembantu kegiatan, laporan pertanggungjawaban pengelola BUMDes dan artikel ilmiah/jurnal ilmiah.

\section{Metode}

Kegiatan awal yang akan dilakukan adalah membangun koordinasi dengan pemerintah dan masyarakat di lokasi KKN-PM STIE Muhammadiyah Palopo. Koordinasi ini sangat penting agar 
pada saat pelaksanaan kegiatan sinergitas dapat tercapai. Kemudian perencanaan disusun secara bersama antara masyarakat pemerintah, pendamping KKN-PM, dan pihak pusat penelitian dan pengabdian (P3M) kepada masyarakat. Koordinasi perencanaan ini dilakukan dalam rangka melakukan rekruitmen mahasiswa peserta KKN-PM, khususnya yang berhubungan dengan kegiatan pendampingan manajemen keuangan BUMDes.

Mahasiswa peserta KKN-PM akan dibekali melalui pemaparan dan pelatihan mengenai kegiatan yang dilakukan selama 2 hari, dengan materi; Penjelasan teknis mengenai KKN-PM, berbagai teknik fasilitasi pemberdayaan masyarakat, dinamika kemiskinan di perdesaan, dan materi teknik penguatan kelompok. Selain itu, juga akan dibahas rencana kerja dan jadwal kegiatan, akomodasi dan ketentuan-ketentuan yang mengikat mahasiswa peserta KKN-PM selama berada di lokasi kegiatan. Setelah pembekalan, mobilisasi mahasiswa peserta KKN-PMdilakukan. Penyerahan secara resmi mahasiswa peserta KKN-PM kepada pemerintah setempat sebagai tanda dimulainya pelaksanaan KKN-PM.

Langkah-langkah dalam bentuk program yang akan dilaksanakan adalah program pemberdayaan masyarakat melalui peningkatan pengelolaan badan usaha milik desa (BUMDes) di Desa Ladongi, Kecamatan Malangke Kabupaten Luwu Utara. Provinsi Sulawesi Selatan. Metode yang digunakan dalam melakukan Pemberdayaan Masyarakat Melalui Peningkatan Pengelolaan Badan Usaha Milik Desa (BUMDes) melalui lokakarya dengan pelatihan agar sasaran bisa tercapai sesuai harapan pengelola BUMDes, aparatur dan masyarakat desa setempat.

\section{Hasil Dan Pembahasan}

Kegiatan pelaksanaan pendampingan BUMDes dijabarkan dilaksanakan dalam bentuk kunjungan resmi ke kantor Bumdes yang terletak di kantor desa Ladongi dalam hal ini didampingi oleh kepala desa serta para pengelola BUMDes, serta konsultas via telefon yang dilakukan oleh mahasiswa sebagai pendamping kegiatan KKN-PM STIE Muhammadiyah Palopo. Pada kunjungan awal/observasi awal, kegiatan difokuskan untuk mengetahui profil, struktur organisasi dan jenis kegiatan BUMdes. Dari hasil observasi diketahui bahwa jenis kegiatan, struktur dan pengurus telah ditentukan dengan jelas, tetapi pengurus belum bisa menunjukkan bukti dokumentasi, karena dokumentasi AD/ART belum tersedia. Struktur organisasi secara tertulis belum tampak di kantor BUMDes. Selain itu, team pendamping menemukan bahwa bukti pembelian dan penjualan barang dagangan yang menjadi kegiatan utama BUMDes juga belum dibuat sebagaimana mestinya. Dari segi pencatatan transaksi keuangan /pembukuan. Pembukuan hanya berupa penjualan dan pembelian yang dimulai sejak BUMDes berdiri (Februari 2018). Sistem pencatatan transaksi 
dilaksanakan secara manual.

Namun dari obeservasi awal, karyawan BUMDes mengakui bahwa masih mengalami kesulitan dalam mengelola sistem keuangan walaupun secara sederhana dan masih mengalami kesulitan dalam pengoperasian MS. Excel, sehingga yang utama masih mengandalkan pencatatan manual. Hal ini lazim dialami beberapa unit usaha yang dimiliki pemerintah desa (Mutiarni, 2017), tidak hanya di BUMDes Ladongi. Selain itu, dari hasil observasi awal tersebut, diketahui terdapat selisih saldo masuk dan keluar yang ada di buku dengan yang tertulis serta baik bendahara maupun ketua BUMDes tidak dapat menunjukkan bukti-bukti transaksi yang sah.

Dari hasil observasi tersebut, maka tim pendamping menentukan rencana kerja untuk selanjutnya. Tim akan memastikan kelengkapan data atau dokumen BUMDes. Selain itu, tim juga akan menyusun standar operasional perusahaan (pengaturan tentang sistem dan alur kegiatan antara proses pembelian, penjualan dan pelaporannya baik ke BUMDes maupun ke kepala desa). Tim pendamping akan memberikan pelatihan manajemen keuangan dan pelaporannya kepada pengurus BUMDes. Agar lebih memudahkan pekerjaan untuk selanjutnya, tim akan membuat daftar akun yang sesuai dengan ETAP.

Dari hasil obeservasi awal sebagaimana disebutkan di atas, selanjutnya tim pendamping mulai melakukan beberapa perbaikan dan pelatihan sesuai kondisi yang dibutuhkan. Tim melakkukan pelatihan pembukuan /pencatatan transaksi menggunakan Excel yang sudah dikelola sedemikian rupa sehingga karyawan BUMDes bisa mengentry/memasukkan transaksi harian dan laporan keuangan sederhana akan otomatis tersaji (Mutiarni, Utomo, \& Zuhroh, S. 2017).

Selain itu, tim pendamping juga membuat draft tentang ketentuan dan prosedur pembelian, penjualan dan pertanggung jawabannya ke BUMDes dan kepala Desa. Setelah melakukan pelatihan pemanfaatan Microsoft Excel (Ms. Excel) beberapa kali dan mitra dianggap telah mampu, selanjutnya tim pendamping memberikan pemahaman tentang tiga laporan keuangan yaitu laporan laba/rugi, neraca, dan arus kas yang merupakan standar pelaporan kuangan untuk akuntansi perusahaan jasa. Untuk pelatihan pembuatan laporan keuangan, tim pendamping perlu mengulang/melakukan beberapa kali. Hal ini terjadi, karena mitra belum pernah mendapat pelatihan serupa sebelumnya. Namun setelah melewati proses latihan, mencoba memasukkan transaksi sendiri, tim melihat bahwa mitra telah mampu untuk melanjutkan sendiri sistem pencatatan transaksi hingga penyajian laporan keuangan pada bulan-bulan berikutnya.

Namun demikian, tim pendamping bersifat terbuka, apabila di masa mendatang petugas/karyawan Bumdes Ladongi masih membutuhkan bantuan, tim akan dengan senang hati memberikan bantuan. 


\section{Simpulan}

Dari hasil pendampingan BUMDes di Desa Ladongi, Kecamatan Malangke, Kabupaten Luwu Utara, Propinsi Sulawesi Selatan pada saat observasi awal disimpulkan bahwa masih terdapat banyak kelemahan dan keterbatasan, sehingga memerlukan pendampingan untuk perbaikan. Keterbatasan itu antara lain: 1) Kegiatan pengelolaan keuangan belum berjalan dengan baik sesuai kaidah pembukuan dan pelaporan keuangan dilihat dari sisi pembukuan dan atau akuntansi; 2) Pengurus inti BUMDes juga belum mengetahui posisi keuangannya per tahun 2018; 3) Penentuan tarif retribusi pasar dan sewa kios belum jelas; 4) Bagi hasil atau pertanggung jawaban pengelola/pengurus BUMDes ke kepala Desa Ladongi juga belum jelas; 5) Sistem penggajian untuk pengurus BUMDes belum jelas; 6) Belum terampilnya pengurus BUMDes terhadap teknologi komputer yang bisa digunakan di kantor BUMDes, sehingga menghambat kelancaran input pembukuan dan 7) Pencatatan transaksi yang masih terus membutuhkan pelatihan sehingga bisa memenuhi standar akuntansi yang dipakai dan peraturan pelaporan BUMDes.

Setelah melalui program pendampingan yang dilakukan oleh tim, maka mitra binaan (BUMDes Ladongi) telah mencapai beberapa kemajuan. Namun demikian, pendampingan tersebut tidak bisa berhenti setelah kegiatan selesai. Disarankan, pemerintah desa Ladongi untuk lebih proaktif melakukan konsultasi kepada tim pendamping atau pihak lain yang kompeten, agar BUMDes Ladongi lebih maju dan berkembang.

\section{Ucapan Terima kasih}

Terima kasih kepada Masyarakat serta perangkat pemerintahan Desa Ladongi, Kabupaten Luwu Utara atas dukungan serta kerja sama hingga pengabdian masyarakat ini dapat terlaksana dengan baik.

\section{Daftar Pustaka}

Hidayat, A.T, Pujiati, L, Hidyati, N, Hendrawan, S.A, Suprapto, S dan Nurali, N. 2018. Pendampingan Penyusunan Laporan Keuangan Pada Badan Usaha Milik Desa (Bumdes) Lestari Desa Bandung Kecamatan Diwek Jombang. COMVICE, 2(1). 15-20.

Mutiarni, R., Utomo, L. P., \& Zuhroh, S. 2017. Pendampingan Pencatatan Transaksi Keuangan Pada Koperasi Bunga Harapan Desa Ceweng. Comvice. Journal of Community Service, 1(1), 33-38.

Mutiarni, R. 2017. Implementasi Electronic Data Processing Pada Koperasi Wanita. Eksis: Jurnal Riset Ekonomi dan Bisnis, 12(2), 135-148. 
Sari, Harmita. \& Hafid Anita. 2019. Pengembangan Usaha Kerupuk Amplang Bandeng untuk Memberdayakan Masyarakat Desa Polejiwa Kecamatan Malangke Barat Kabupaten Luwu Utara Provinsi Sulawesi Selatan. Panrita Abdi Jurnal Pengabdian Kepada Masyarakat, 3(2), 161-169.

Undang-undang Nomor 10 Tahun 1998 tentang Perubahan Atas Undang-Undang Nomor 7 Tahun 1992 tentang Perbankan

Undang-Undang Republik Indonesia Nomor 17 Tahun 2012 tentang perkoperasian

Undang-undang Republik Indonesia Nomor 25 Tahun 1992 Tentang Perkoperasian 